\title{
Value of Platelet Activation Markers as Prothrombotic Risk Indicators
}

\author{
Wolfgang Lösche ${ }^{a}$ Stan Heptinstall ${ }^{b}$ \\ a Department of Anaesthesiology and Intensive Care Medicine, University Hospital Jena, Germany \\ bDivision of Cardiovascular Medicine, Queen's Medical Centre, University Hospital Nottingham, UK
}

\section{Key Words}

Platelet activation marker · MPV · Platelets · Haemostasis · Thrombosis

\section{Summary}

Platelets adhere to the subendothelium that is exposed at sites of vessel wall injury to form a primary haemostatic plug by aggregating together. Activated platelets support fibrin formation by exposing a procoagulant surface and encrypting circulating tissue factor. Through this process platelets are essential components of haemostasis and also of arterial thrombosis. Evidence has been provided that detection of circulating activated and/or hyperreactive platelets may indicate a high thrombotic risk. The aim of the present review is to present an overview of the various parameters that can be measured and that provide information on platelet activation and reactivity, such as changes in platelet surface membrane properties (e.g. CD62P expression, binding of PAC-1, fibrinogen or annexin $\mathrm{V})$, release of stored compounds (e.g. $\beta$-thromboglobulin, platelet factor 4 or $\mathrm{CD} 62 \mathrm{P}$ ), formation of procoagulant membranous microvesicles, measurements of platelet adhesion, platelet aggregation and platelet-leukocyte conjugate formation and changes in platelet volume. The methods that can be used to measure the various parameters are briefly described. We also refer to various pitfalls in pre-analysis and data interpretation. Throughout we direct the readers' attention to published studies that indicate the potential value of the various measured parameters as indicators of thrombotic risk.

\section{Schlüsselwörter}

Thrombozytenaktivierungsmarker - MPV - Thrombozyten . Hämostase · Thrombose

\section{Zusammenfassung}

Thrombozyten adhärieren an subendotheliale Strukturen an der Stelle einer Gefäßverletzung, aggregieren miteinander und bilden damit den primären hämostatischen Pfropf. Aktivierte Thrombozyten unterstützen die Fibrinbildung durch Ausbildung einer prokoagulanten Oberfläche und durch Demaskierung von zirkulierenden Tissue factor. Infolge dieser Prozesse sind Thrombozyten eine entscheidende Komponente der Hämostase und tragen wesentlich zur Entstehung arterieller Thrombosen bei. Es gibt zahlreiche Hinweise dafür, dass der Nachweis von aktivierten und/oder hyperreaktiven Thrombozyten ein erhöhtes Risiko für thrombotische Ereignisse anzeigen kann. Ziel des vorliegenden Artikels ist es, einen Überblick über die verschiedenen Parameter, die zur Charakterisierung einer Thrombozytenaktivierung oder -reaktivität bestimmt werden können, zu geben. Dazu gehören Veränderungen in Eigenschaften der Plasmamembran (z.B. CD62P-Expression, Bindung von Fibrinogen, PAC-1 oder Annexin V), Freisetzung von Molekülen aus intrazellulären Speichern (z.B. $\beta$ Thromboglobulin, Plättchenfaktor 4 oder CD62P), Bildung prokoagulanten Membranvesikel, Messung der Thrombozytenadhäsion, der Thrombozytenaggregation und der Bildung von Thrombozyten-Leukozyten-Konjugaten sowie Veränderungen des Thrombozytenvolumens. Die Methoden für die Bestimmung der verschiedenen Parameter werden kurz beschrieben. Auf mögliche Fehler in der Präanalytik und der Dateninterpretation wird hingewiesen. Weiterhin werden Ergebnisse aus zahlreichen Studien, die den potenziellen Wert der verschiedenen Parameter für die Abschätzung eines thrombotischen Risikos anzeigen, vorgestellt. 


\section{Role of Platelets in Haemostasis, Thrombosis and Inflammation}

Platelets are anucleated cell fragments that are derived from megakaryocytes. Due to their ability to adhere to the vessel wall at sites of vessel injury and to form a primary haemostatic plug by aggregating together, platelets are very important players in haemostasis [1,2]. At the site of vessel injury platelets undergo initial activation via two main mechanisms:

- binding of subendothelial von Willebrand factor (vWF) and collagen to receptors on the platelet surface [3-7],

- cleavage of the platelet thrombin receptor by thrombin that is formed due to the exposure of subendothelial tissue factor (TF) to the blood stream [8-10].

The activated platelets are able to bind fibrinogen as well as vWF to glycoprotein IIb/IIIa complex (GPIIb/IIIa) on the platelet surface, resulting in platelet aggregation and the formation of a platelet-rich thrombus $[11,12]$. Once activated, platelets contribute via various mechanisms to the formation of thrombin and fibrin as well as to the firmness and stability of the fibrin clot. These include:

- translocation of negatively charged phospholipids, in particular phosphatidylserine (PS), from the inner to the outer leaflet of the plasma membrane, which provide binding sites for various coagulation factors [13-17];

- production of platelet microvesicles (PMV) that are less than $1 \mu \mathrm{m}$ in diameter as a consequence of re-organisation of the platelet membrane; PMV also expose large amounts of PS on their surface, enabling them to bind and activate coagulation factors in a similar way as native platelets $[15$, 16, 18, 19];

- exposure of TF on activated platelets and PMV [20-22]. Evidence has been provided that platelet-derived TF becomes activated when platelets or PMV adhere to leucocytes through a receptor-mediated mechanism that involves P-selectin (CD62P) on the surface of platelets and PMV and P-selectin glycoprotein ligand-1 (PSGL-1) on the surface of leucocytes [22-25]. On the other hand, platelets have shown to activate 'blood-borne' TF at the site of platelet activation, i.e. at the site of vessel wall injury [26]. Monocytes have been shown to contribute to 'blood-borne' TF by shedding TF-bearing microvesicles from their surface membrane. TF on monocyte-derived microvesicles seems to be encrypted and becomes decrypted when the microvesicles interact with activated platelets via PSGL-1 and CD62P [27-29]. It has also been reported that adhesion of platelets to monocytes that is mediated by CD62P and CD40 ligand (CD40L or CD154) induces a de-novo synthesis of TF in monocytes [30, 31].

As a consequence of these various functions, platelets not only play an essential role in haemostasis, but they are also major players in thrombosis, in particular in thrombi that develop in arteries and in the microcirculation. A main cause of arterial thrombosis leading to myocardial infarction, ischaemic stroke or peripheral arterial occlusion is the presence of atherosclerotic plaques. When such plaques rupture, platelets become activated due to contact with exposed collagen fibres and vWF in the subendothelial matrix. Indirect activation is due to the exposure of plaque-associated $\mathrm{TF}$ and the formation of thrombin $[12,32,33]$. Today atherosclerosis is considered to be an inflammatory disease, and platelets are believed to contribute to the development of atherosclerotic plaques, mainly due to a contribution to inflammatory reactions within the vessel wall [34].

Platelets, vWF and the vWF-cleaving protease ADAMTS-13 (A Disintegrin And Metalloproteinase with a ThromboSpondin type 1 motif) have now been recognised as major players in thrombotic microangiopathies. The thrombotic microangiopathies are microvascular occlusive disorders characterised by systemic or intrarenal platelet aggregation, thrombocytopenia and mechanical injury to erythrocytes. In thrombotic thrombocytopenic purpura, systemic microvascular aggregation of platelets results in ischemia in the brain and other organs [35]. The most severe form of this kind of disease, the thrombotic thrombocytopenic purpura (TTP) firstly described by Ely Moschcowitz in 1924 [36], is caused by a hereditary or acquired deficiency of ADAMTS-13. It is a consequence of a hereditary or acquired deficiency of ADAMTS-13. Due to a lack of or a markedly decreased enzyme activity, ultra large vWF multimers are insufficiently cleaved and induce activation of platelets at sites of high shear forces, i.e. within the microcirculation [35, 37].

In addition to their essential role in haemostasis and thrombosis, platelets are now recognised as an inflammatory cell. Activated platelets secrete various factors that act as signals to target cells of the innate and adaptive immune system. Some of the secreted factors are proteins and peptides, such as cytokines and chemokines, growth factors, antimicrobial peptides or bioactive amines; other factors are rapidly synthesised when platelets becomes activated (e.g. lipid mediators such as thromboxane $\mathrm{A}_{2}$ or platelet-activating factor) [38-40]. Another mechanism by which platelets and PMV communicate with cells of the immune system is receptor-mediated contact. Changes in the generation of reactive oxygen species, in phagocytic and adhesion activity and in the expression of genes with relevance to the inflammatory response of the target cells have been described [41-46]. However, the mechanisms involved in the modulation of immune response by platelets or PMV are not yet completely understood.

\section{Markers of Platelet Activation and Platelet Hyperreactivity}

As outlined above, platelets are implicated in the pathophysiology of thrombosis as well as inflammation. In consequence, they also had an impact on the morbidity and mortality associated with such conditions. With respect to thrombosis, success- 
ful outcomes after administration of inhibitors of platelet function such as aspirin, clopidogrel and GPIIb/IIIa antagonists have provided further evidence of the importance of platelets in cardiovascular disease. Consequently, the identification of subjects with inappropriate platelet function could help to determine patients at risk of thrombosis and also appropriate means of risk reduction. In principle there are two ways to assess the behaviour of platelets in patients at risk:

- To look for evidence of platelet hyperreactivity, i.e. to determine whether the platelet response to a given stimulus is higher when compared with that of control subjects. Such studies can be performed in vitro.

- To look for an evidence of in vivo platelet activation. For such studies platelets of patients are analysed ex vivo without any additional stimulation.

There are manifold functions of platelets, and the various aspects of platelet activation result in many and quite different tests to determine platelet reactivity. Parameters that describe platelet reactivity and/or in vivo platelet activation can be divided in several categories:

- interaction of platelets with cells or matrices

- adhesion of platelets to artificial or natural surfaces or matrices

- platelet-platelet aggregation

- adhesion of platelets to leucocytes or endothelial cells,

- changes at the platelet membrane

- translocation of molecules from intracellular compartments to the membrane surface

- conformational changes of surface receptors

- binding of extracellular molecules to the membrane,

- release of platelet material into the surrounding plasma

- secretion of molecules that are stored inside platelets or that are synthesised when platelets become activated

- shedding of surface-exposed molecules

- shedding of membranous microvesicles,

- changes in the platelet proteome,

- changes in the platelet volume and density.

To discuss all the methods that are described in the literature would exceed the limits of this review. Therefore, only the most import and widely used methods will be reviewed. The order they will be introduced here will not follow the categorisation as given above.

\section{Platelet Aggregation}

Measurement of spontaneous or agonist-induced platelet aggregation is the most commonly used method to determine platelet reactivity. Platelet aggregation is mediated by the binding of fibrinogen to its receptor (GPIIb/IIIa, CD41) and the consequent bridging of platelets together. In 1962 Gustav Born [47] introduced an elegant method to determine platelet aggregation by simple measurement of light transmission in a stirred sample of platelet-rich plasma (PRP) or washed platelets. Although this method is still widely used today, it has the disadvantage that platelets have to be isolated from the other blood cells. To avoid the procedure of platelet isolation and to have the opportunity to investigate the influence of other blood cells on platelet aggregation, whole blood methods were developed. One possibility to measure whole blood platelet aggregation is based on the counting of the number of single platelets [48] or on the measurement of electrical impedance of blood which changes when platelets adhere and aggregate on special platinum electrodes [49]. Platelet aggregation results in a fall in the number of single platelets or an increase in impedance [48-50]. As platelet counts already change when very small aggregates that consist of only few platelets are formed, the counting technique can also monitor the formation of microaggregates that cannot be detected by light transmission or impedance measurements $[51,52]$.

Another method to measure platelet micro- and macroaggregation in samples of whole blood is flow cytometry. This method also quantitates platelet aggregation by counting the number of single platelets, but microaggregates can also be directly visualised $[53,54]$. According to the basic principle of flow cytometry, platelets are identified by their light scatter characteristics as well as by the binding of a fluorescencelabelled antibody directed against a platelet-specific antigen, e.g. CD41 or CD42. Formation of microaggregates is characterised by an increase in the size, i.e. the forward light scatter, as well as by a decrease in the number of the platelet-positive events. To get absolute numbers for single platelets or platelet microaggregates, it has been recommended to determine the platelet / red blood cell (RBC) ratio by flow cytometry and to determine the absolute RBC count in the whole blood sample using standard laboratory methods $[54,55]$.

An instrument that measure in parallel matrix-platelet adhesion and platelet aggregation is the Platelet Function Analyser PFA 100 (Dade Behring, Eschborn, Germany). The instrument measures the closure time of the aperture of the cartridge that is covered with platelet agonists, i.e. collagen + ADP or collagen + epinephrine. PFA 100 is probably more capable to detect decreased rather than increased platelet activity $[56,57]$.

There are also some reports in the literature describing circulating platelet aggregates in patients with high thrombotic risk. For example, there is a report of platelet aggregates in blood from TTP patients detected using flow cytometry [58].

\section{Changes in Platelet Membrane Surface Receptors}

Platelet activation results in a reorganisation of the plasma membrane that can be rather easily detected by flow cytometry and can be used for measurement of platelet activation in vivo as well as to evaluate platelet reactivity. One of the advantages of flow cytometry is that only minuscule volumes $(5 \mu \mathrm{l})$ of blood are required. However flow cytometry has also some disadvantages when analysing in vivo activation. One of them is that blood samples have to be analysed within $30 \mathrm{~min}$ to avoid ex vivo platelet activation. For some but not all of the 
parameters that can be determined, the time issue can be circumvented be immediate fixation of the blood sample $[59,60]$. A conformational change in GPIIb/IIIa is a prerequisite for fibrinogen binding and platelet aggregation. The change on GPIIb/IIIa is associated with the appearance of a new epitope that is recognised by the monoclonal antibody PAC- 1 . Thus PAC-1 binds to activated but not to resting platelets [61]. Activated GPIIb/IIIa can be also detected using either fluorescence-labelled fibrinogen or an antibody against fibrinogen $[62,63]$. Increased binding of PAC-1 and/or fibrinogen has been reported in patients with myocardial infarction, stroke, sepsis and anti-phospholipid syndrome as well as in postmenopausal women who are known to have an increased thrombotic risk [64-68].

The most widely studied activation marker on the platelet surface is CD62P. There are many reports on increased expression of this antigen on platelets in patients with various kinds of disease associated with thrombotic risk, and very often increased CD62P expression is associated with increased binding of PAC-1 or fibrinogen $[66,68,69]$. It has been recently reported that high CD62P expression on circulating platelets is strongly associated with adverse clinical outcomes after an early ischaemic stroke [70]. When determining platelet CD62P as a platelet activation marker, one has to consider that the molecule is also shed from circulating platelets [71-73]. Furthermore, as mentioned above, CD62P mediates the adhesion of activated platelets to monocytes and neutrophils in a process that involves PSGL-1 on the leucocyte surface [74].

There are some other receptor molecules that can be measured by flow cytometry as indicators of platelet activation, e.g.

- the $\alpha$-granule membrane protein GMP-33 [75,76],

- the lysosomal protein CD63 the expression of which has been shown to be increased for example in patients with venous thrombosis or type 2 diabetes mellitus [77, 78], or

- the CD40L that is involved in the interaction of platelets with leucocytes and that is believed to trigger pro-inflammatory signalling [79-83].

\section{Platelet-Leukocyte Conjugates}

The fact that activated CD62P-positive platelets readily adhere to monocytes and neutrophils make circulating plateletleucocyte conjugates a very sensitive marker of platelet activation. Platelet-leucocyte conjugates can be easily identified by whole blood flow cytometry as leucocytes staining positive for a platelet-specific antigen such as CD41 or CD42a. Leucocytes can be differentiated from other cells and from each other by their light scatter characteristics and also by using antibodies to cell-specific surface antigens, e.g. CD14 on monocytes. Thus it is possible to distinguish conjugates that are formed from platelets adherent to neutrophils, to monocytes or to lymphocytes [84, 85]. As mentioned above and discussed in more detail below, platelet activation also results in the shedding of membranous microvesicles form the platelet plasma membrane. These PMV express various surface receptors similar to activated platelets. Thus, PMV can also adhere to leucocytes. However, flow cytometry cannot distinguish whether platelets or PMV adhere to leucocytes forming a platelet-leucocyte conjugate. Nevertheless, both adhesion of activated platelets or of PMV to leucocytes reflect platelet activation $[86,87]$. Another aspect of determining platelet-leucocyte adhesion is related to the approach taken to evaluate the flow cytometric data obtained. Adhesion of platelets or PMV to leucocytes is characterised by an increase in the platelet-specific fluorescence signal associated with the leucocyte subspecies. There are two ways to express the amount of conjugate formation: as percentage of 'platelet-positive' leucocytes or as the fluorescence intensity of the platelet-specific fluorescence given as either mean or median fluorescence intensity per leucocyte. The number of platelet-positive leucocytes that is obtained by setting a threshold for the fluorescence intensity does not consider the number of adhering platelets or PMV. On the other hand, mean fluorescence intensity is a measure of the total 'load' of leucocytes with the platelet-specific antigen, i.e. it is a measure of the number of platelets and PMV bound to each leucocyte $[85,88]$. To have both measures, the number of platelet-positive leucocytes and also the mean fluorescence per leucocyte, may be especially helpful when investigating platelet-leucocyte adhesion in patients receiving GPIIb/IIIa antagonists such as abciximab (Reopro ${ }^{\circledR}$, Eli Lilly and Company, Indianapolis, IN, USA) or eptifibatide (Integrilin ${ }^{\circledR}$, GlaxoSmithKline, Middlesex, UK). As such compounds are highly effective in inhibiting platelet-platelet aggregation but do not prevent platelet activation and CD62P expression, they can increase the number of platelet-positive leucocytes (due to a high number of single CD62P-positive platelets) but decrease the mean fluorescence of the platelet-positive leucocytes (no adhesion of platelet aggregates). Such phenomenon could explain the inconsistent data on the effects of GPIIb/IIIa antagonists on platelet-leucocyte adhesion [88-91].

With respect to leucocyte subspecies, platelets or PMV adhere more easily to monocytes when compared to neutrophils [71, $84,92,93]$. Thus quantitation of circulating platelet-monocyte conjugates is considered to be a particularly sensitive means of determining platelet activation in vivo [71,94]. The number of circulating platelet-monocyte conjugates is increased in various clinical conditions that are associated with platelet activation and increased thrombotic risk [71, 94-98].

Circulating platelet-leucocyte conjugates may not only indicate platelet activation in vivo but may be also implicated in thrombus formation. Some evidence has been provided that activated platelets as well as PMV express TF, the most important activator of intravascular coagulation, on their surface $[21,86,99]$. However, adhesion of platelets and PMV with leucocytes also seems to be important in generating actual procoagulant activity $[22,25,100]$. 


\section{Platelet Procoagulant Activity and PMV}

Activation of platelets is associated with a translocation of negatively charged phospholipids, in particular PS, from the inner to the outer leaflet of the plasma membrane. PS exposure at the platelet surface is not only an indicator of platelet activation, but proves essential for the binding and activation of some plasma coagulation factors resulting in the amplification and propagation of thrombin and fibrin formation [13-17]. In addition to PS, there is also some evidence for the existence of specific 'non-lipid' receptors for factors $\mathrm{X}(\mathrm{a})$, $\mathrm{XI}(\mathrm{a})$ and VIII(a) on the surface of activated platelets as reviewed by Hoffman and Monroe [8].

In 1985, a protein was isolated from umbilical cord arteries that inhibited blood coagulation by affecting the interaction between coagulation factors and phospholipids, and later it was identified as annexin V [101, 102]. Due to its high affinity to PS on cell surfaces, annexin V is widely used to detect PS exposure of activated platelets; annexin $\mathrm{V}$ binding is considered as a measure of the platelet procoagulant activity [103-105].

When measuring annexin $\mathrm{V}$ binding to detect platelet activation it has to be considered that PS translocation is one of the mechanisms that are involved in the shedding of PMV from the platelet plasma membrane. Thus one may speculate that most of the translocated PS is associated with PMV rather than with the activated platelets [16, 106-108]. Indeed there are considerably more reports on increased numbers of annexin V-positive PMV in various clinical conditions when compared to reports on annexin V-positive platelets.

In principle there are two ways to measure PMV in samples of whole blood or plasma: flow cytometry or enzyme-immunoassay (ELISA). Using flow cytometry, PMV can be identified by their light scatter characteristics and by the binding of an antibody that is directed against a platelet-specific antigen such as CD41 or CD42a. Additionally some authors use annexin $\mathrm{V}$ binding as a unique characteristic of cell-derived microvesicles and as a measure of the PMV procoagulant activity $[105,109,110]$. Using flow cytometry, PMV can be detected in samples of whole blood, PRP or platelet-poor plasma (PPP), but some authors prefer to isolate microvesicles from blood or plasma samples prior to staining with a platelet-specific antibody (and annexin V) [111, 112]. When measuring PMV in samples of whole blood or PRP, one has to define a size threshold on the forward scatter versus fluorescence dot plot or histogram to distinguish between PMV and the smallest intact platelets. To solve this problem, microspheres with a diameter of $1 \mu \mathrm{m}$ or less can be used to set the threshold [113, 114]. Another possibility is to define the threshold in such a way that only a certain percentage (1-5\%) of all platelet-positive events is below it. Of course, an unstimulated whole blood or PRP sample of healthy individuals have to be used to set the threshold $[115,116]$. When measuring PMV in cell-free samples, i.e. in PPP or suspensions of washed PMV, there is no problem in discriminating between PMV and platelets. To pre- pare PMV-containing PPP, various centrifugation protocols are used, e.g. $15 \mathrm{~min}$ at $700 \times g$ and up to $5 \mathrm{~min}$ at $5,000 \times \mathrm{g}$. For isolating PMV from plasma high speed centrifugation, such as $1 \mathrm{~h}$ at $13,000 \times \mathrm{g}$, is necessary [86,117, 118]. A further problem concerns the enumeration of PMV. Probably the best method is to add to the sample a defined number of fluorescence-labelled counting beads that are provided by various companies. These beads can be identified and counted in the flow cytometer and used to calculate the number of PMV per sample volume, i.e. per millilitre blood or plasma $[53,118]$. Another possibility is to calculate the number of PMV in the samples on the basis of the flow volume that is passed through the flow cytometer. However, this method requires to ascertain a constant flow in the instrument $[112,117]$. When measurements are done in samples of whole blood or PRP, it is also possible to express the number of PMV in relation to the total number of platelet-positive events that are measured [69, $116,119]$. While a good correlation was reported between the relative and absolute numbers of PMV when measured in samples of healthy individuals or patients with activated platelets, a poor correlation was found when measured before and after in vitro platelet activation $[115,118,120]$.

Flow cytometry has been widely used to demonstrate increased levels of circulating microvesicles indicating platelet activation in various clinical conditions such as myocardial infarction [112, 121, 122], percutaneous transluminal coronary angioplasty (PTCA) [117, 123], peripheral arterial disease $[112,124]$, sepsis $[111,125-128]$, TTP $[120,129,130]$ or preeclampsia [131].

ELISA technique has been also employed to measure PMV. Osumi et al. [132] used monoclonal antibodies directed to various platelet-specific antigens to capture PMV from PPP samples and used second antibodies to quantify the amount of captured PMV. This method was successfully used to monitor changes in platelet function in patients undergoing PTCA [133].

\section{Soluble Plasma Markers of Platelet Activation}

This topic has been excellently reviewed by Gurney et al. [134] in 2002. From the huge number of molecules that are released from activated platelets only a few appeared to be reliable markers of platelet activation. There are two proteins that are released from the platelet $\alpha$-granules: platelet factor 4 and $\beta$ thromboglobulin. The plasma levels of both have been shown to be elevated in clinical conditions that are associated with platelet activation and increased thrombotic risk including hypertension, coronary artery disease, diabetes mellitus and cancer [134].

Despite the fact that it can also be released from endothelial cells, soluble CD62P is also believed to a reliable marker of platelet activation [71-73, 124, 135]. Soluble CD62P in plasma samples is determined by ELISA technique, but this method cannot distinguish between free soluble CD62P and CD62P that is expressed on PMV. By exploring plasma samples ob- 
tained from healthy volunteers, we could recently shown that removal of PMV and other circulating cellular microvesicles by ultracentrifugation resulted only in a partial reduction of the CD62P level, indicating that more than $50 \%$ of plasma CD62P is soluble and not bound to microvesicles [86].

Recently, soluble glycoprotein V (GPV) has attracted increasing interest as a marker of platelet activation. Expression of GPV is restricted to platelets and megakaryocytes. Together with GPIb and GPIX it forms a complex on the surface of platelets that acts as a receptor for vWF and thrombin [136, 137]. Release of GPV from activated platelets is believed to be mediated by a cleavage of the molecule by thrombin [138, 139]. Increased GPV plasma levels have been reported in patients with coronary and peripheral atherosclerosis [140-142].

\section{Mean Platelet Volume}

The mean platelet volume (MPV) as a measure of platelet size can be easily determined by haematology analysers. The consensus is that blood should be collected in a special way using sodium citrate as anticoagulant to avoid artificial swelling of the platelets [143]. In 1983 three reports were published demonstrating a relationship between MPV and myocardial infarction [144-146]. This relation was proved in many further and also in very recent studies, and evidence was provided that high MPV is an independent risk factor of myocardial infarction and a predictor of poor outcome [147-151]. Increased PMV was also shown in patients with ischaemic stroke [143, 152] and other conditions with increased thrombotic risk such as diabetes mellitus, obesity and others [143, 153-156]. Recently MPV was shown to be an independent risk factor for thromboembolic events after heart valve replacement and for stent thrombosis after PTCA $[153,157,158]$.

Despite the fact that it is well accepted that high MPV is a risk indicator of thromboembolic events, the cause of high PMV is not completely understood. There is some evidence for a correlation between megakaryocyte DNA content, i.e. megakary- ocyte polyploidy, and PMV, and both may increase under the condition of an increased platelet consumption [159-161]. PMV is also inversely correlated with platelet number which suggests an influence of platelet production on the values that are obtained. Also there are observations of persistent circulation of large activated platelets in patients after myocardial infarction $[69,158]$. On the other hand large platelets are believed to be haemostatically more active and seem to be consumed at the time of thrombus formation, e.g. at time of myocardial infarction or during an acute coronary syndrome [160-162]. However, this might be expected to reduce overall MPV rather than to increase it.

Summarising, MPV is an easily and rapidly determinable parameter which appears to relate to some thromboembolic events. However, the means through which the MPV is regulated and the implications of this for thrombosis formation need further elucidation.

\section{A Final Warning}

There are many and quite different approaches to measure platelet reactivity and platelet activation, and such approaches can provide some valuable information on the thromboembolic risk. However, irrespective of the method and the parameter that is measured, it has to be considered that platelets are very reactive cells. When removed from the circulation they can spontaneously and rapidly become activated. Therefore, much attention has to be paid to pre-analytic procedures, including blood drawing and sample transportation. If one is not careful, the measured markers of platelet activation can tell us more about concomitant circumstances such as the time that has elapsed between blood sampling and sample analysis or the degree of sample agitation during transportation than about the possible thromboembolic risk in the patients under investigation.

\section{References}

1 George JN: Platelets. Lancet 2000;355:1531-1539.

2 Hartwig JH: The platelet: form and function. Semin Hematol 2006;43:S94-100.

$\checkmark 3$ Ruggeri ZM: Platelet and von Willebrand factor interactions at the vessel wall. Hämostaseologie 2004;24:1-11.

4 Savage B, Sixma JJ, Ruggeri ZM: Functional selfassociation of von Willebrand factor during platelet adhesion under flow. Proc Natl Acad Sci U S A 2002;99:425-430.

$\checkmark 5$ Chen J, Lopez JA: Interactions of platelets with subendothelium and endothelium. Microcirculation 2005;12:235-246.

6 Clemetson KJ, Clemetson JM: Platelet collagen receptors. Thromb Haemost 2001;86:189-197.

7 Gibbins JM: Platelet adhesion signalling and the regulation of thrombus formation. J Cell Sci 2004; 117:3415-3425.

8 Hoffman M, Monroe DM III: A cell-based model of hemostasis. Thromb Haemost 2001;85:958-965.
9 Gerotziafas GT, Chakroun T, Depasse F, Arzoglou P, Samama MM, Elalamy I: The role of platelets and recombinant factor VIIa on thrombin generation, platelet activation and clot formation. Thromb Haemost 2004;91:977-985.

10 Balasubramanian V, Grabowski E, Bini A, Nemerson Y: Platelets, circulating tissue factor, and fibrin colocalize in ex vivo thrombi: real-time fluorescence images of thrombus formation and propagation under defined flow conditions. Blood 2002;100: 2787-2792.

$11 \mathrm{Ni} \mathrm{H}$, Freedman J: Platelets in hemostasis and thrombosis: role of integrins and their ligands. Transfus Apher Sci 2003;28:257-264.

12 Steinhubl SR, Moliterno DJ: The role of the platelet in the pathogenesis of atherothrombosis. Am J Cardiovasc Drugs 2005;5:399-408.

13 Monroe DM, Hoffman M, Roberts HR: Transmission of a procoagulant signal from tissue factorbearing cell to platelets. Blood Coagul Fibrinolysis 1996;7:459-464.
14 Butenas S, Branda RF, van't Veer C, Cawthern KM, Mann KG: Platelets and phospholipids in tissue factor-initiated thrombin generation. Thromb Haemost 2001;86:660-667.

15 Heemskerk JW, Bevers EM, Lindhout T: Platelet activation and blood coagulation. Thromb Haemost 2002;88:186-193.

16 Solum NO: Procoagulant expression in platelets and defects leading to clinical disorders. Arterioscler Thromb Vasc Biol 1999;19:2841-2846.

17 Lentz BR: Exposure of platelet membrane phosphatidylserine regulates blood coagulation. Prog Lipid Res 2003;42:423-438.

18 Eilertsen KE, Osterud B: The role of blood cells and their microparticles in blood coagulation. Biochem Soc Trans 2005;33:418-422.

19 Holme PA, Brosstad F, Solum NO: Platelet-derived microvesicles and activated platelets express factor Xa activity. Blood Coagul Fibrinolysis 1995;6:302310 . 
20 Camera M, Frigerio M, Marenzi GC, Salvioni A, Biglioli P, Tremoli E: Platelet-associated tissue factor expression in patients with unstable coronary artery disease. J Thromb Haemost 2003;1(suppl 1): OC009.

21 Siddiqui FA, Desai H, Amirkhosravi A, Amaya M, Francis JL: The presence and release of tissue factor from human platelets. Platelets 2002;13:247-253.

-22 Zillmann A, Luther T, Muller I, Kotzsch M, Spannagl M, Kauke T, Oelschlagel U, Zahler S, Engelmann B: Platelet-associated tissue factor contributes to the collagen-triggered activation of blood coagulation. Biochem Biophys Res Commun 2001;281:603-609.

-23 Scholz T, Temmler U, Krause S, Heptinstall S, Lösche W: Transfer of tissue factor from platelets to monocytes: role of platelet-derived microvesicles and CD62P. Thromb Haemost 2002;88 (6):10331038.

24 Engelmann B, Luther T, Muller I. Intravascular tissue factor pathway - a model for rapid initiation of coagulation within the blood vessel. Thromb Haemost 2003;89:3-8.

25 Lösche W: Platelets and tissue factor. Platelets 2005;16:313-319.

-26 Giesen PL, Rauch U, Bohrmann B, Kling D, Roque M, Fallon JT, Badimon JJ, Himber J, Riederer MA, Nemerson Y: Blood-borne tissue factor: Another view of thrombosis. Proc Natl Acad Sci U S A 1999; 96:2311-2315

-27 Falati S, Liu Q, Gross P, Merrill-Skoloff G, Chou J, Vandendries E, Celi A, Croce K, Furie BC, Furie $\mathrm{B}$ : Accumulation of tissue factor into developing thrombi in vivo is dependent upon microparticle P-selectin glycoprotein ligand 1 and platelet Pselectin. J Exp Med 2003;197:1585-1598.

28 Del Conde I, Shrimpton CN, Thiagarajan P, Lopez JA: Tissue-factor-bearing microvesicles arise from lipid rafts and fuse with activated platelets to initiate coagulation. Blood 2005;106:1604-1611.

29 Furie B, Furie BC: Role of platelet P-selectin and microparticle PSGL-1 in thrombus formation. Trends Mol Med 2004;10:171-178.

30 Celi A, Pellegrini G, Lorenzet R, De Blasi A, Ready N, Furie BC, Furie B: P-selectin induces the expression of tissue factor on monocytes. Proc Nat Acad Sci U S A 1994;91:8767-8771.

31 Lindmark E, Tenno T, Siegbahn A: Role of platelet P-selectin and CD40 ligand in the induction of monocytic tissue factor expression. Arterioscler Thromb Vasc Biol 2000;20:2322-2328.

32 Freedman JE: Molecular regulation of platelet-dependent thrombosis. Circulation 2005;112:2725-2734.

33 Vorchheimer DA, Becker R: Platelets in atherothrombosis. Mayo Clin Proc 2006;81:59-68.

34 Gawaz M, Langer H, May AE: Platelets in inflammation and atherogenesis. J Clin Invest 2005;115 3378-3384.

35 Moake JL: Thrombotic microangiopathies. N Engl J Med 2002;347:589-600.

36 Moschcowitz E: Hyaline thrombosis of the terminal arterioles and capillaries: a hitherto undescribed diseaase. Proc N Y Pathol Soc 1924;24:21-25.

37 Soejima K, Nakagaki T: Interplay between ADAMTS13 and von Willebrand factor in inherited and acquired thrombotic microangiopathies. Semin Hematol 2005;42:56-62.

38 Klinger MH, Jelkmann W: Role of blood platelets in infection and inflammation. J Interferon Cytokine Res 2002;22:913-922.

39 Weyrich AS, Zimmerman GA: Platelets: signaling cells in the immune continuum. Trends Immunol 2004;25:489-495.
40 Gear AR, Camerini D: Platelet chemokines and chemokine receptors: linking hemostasis, inflammation, and host defense. Microcirculation 2003; 10:335-350.

41 Nagata K, Tsuji T, Todoroki N, Katagiri Y, Tanoue K, Yamazaki H, Hanai N, Irimura T: Activated platelets induce superoxide anion release by monocytes and neutrophils through P-selectin (CD62). J Immunol 1993;151:3267-3273.

42 Jancinova V, Drabikova K, Nosal R, Danihelova E: Platelet-dependent modulation of polymorphonuclear leukocyte chemiluminescence. Platelets 2000; 11:278-285.

43 Lösche W, Dressel M, Krause S, Redlich H, Spangenberg P, Heptinstall S: Contact-induced modulation of neutrophil elastase secretion and phagocytic activity by platelets. Blood Coagul Fibrinolysis 1996;7:210-213.

44 Setzer F, Oberle V, Blaess M, Möller E, Russwurm S, Deigner H-P, Claus RA, Bauer M, Reinhart K, Lösche W: Platelet-derived microvesicles induce differential gene expression in monocytic cells: a DNA microarray study. Platelets 2006; (in press).

45 Baj-Krzyworzeka M, Majka M, Pratico D, Ratajczak J, Vilaire G, Kijowski J, Reca R, JanowskaWieczorek A, Ratajczak MZ: Platelet-derived microparticles stimulate proliferation, survival, adhesion, and chemotaxis of hematopoietic cells. Exp Hematol 2002;30:450-459.

46 Diamant M, Tushuizen ME, Sturk A, Nieuwland R: Cellular microparticles: new players in the field of vascular disease? Eur J Clin Invest 2004;34:392-401.

47 Born GV: Aggregation of blood platelets by adenosine diphosphate and its reversal. Nature 1962;194: 927-929.

48 Fox SC, Burgess-Wilson M, Heptinstall S, Mitchell JR: Platelet aggregation in whole blood determined using the Ultra-Flo 100 Platelet Counter. Thromb Haemost 1982;48:327-329.

49 Bertolino G, Noris P, Balduini CL: Effect of different sample preparation methods on the results of the impedance technique in the study of platelet hyper- and hypo-function in whole blood. Thromb Res 1993;71:89-94.

50 Krause S, May J, Koslowski H, Heptinstall S, Losche W: Enhanced spontaneous platelet aggregation and red blood cell fragility in whole blood obtained from diabetics. Platelets 1991;2:203-206.

51 Losche W, Burgess-Wilson M, Michel E, Heptinstall S, Till U: Diamide induces reversible aggregation of human blood platelets. Thromb Res 1985; 40:869-874.

52 Storey RF, Wilcox RG, Heptinstall S: Differential effects of glycoprotein IIb/IIIa antagonists on platelet microaggregate and macroaggregate formation and effect of anticoagulant on antagonist potency : implications for assay methodology and comparison of different antagonists. Circulation 1998;98:1616-1621.

53 Matzdorff AC, Kuhnel G, Kemkes-Matthes B, Pralle H: Quantitative assessment of platelets, platelet microparticles, and platelet aggregates with flow cytometry. J Lab Clin Med 1998;131:507-517.

54 Fox SC, Sasae R, Janson S, May JA, Heptinstall S Quantitation of platelet aggregation and microaggregate formation in whole blood by flow cytometry. Platelets 2004;15:85-93.

55 Harrison P, Ault KA, Chapman S, Charie L, Davis B, Fujimoto K, Houwen B, Kunicka J, Lacombe F, Machin S, Raynor R, van HL, van Assendelft OW: An interlaboratory study of a candidate reference method for platelet counting. Am J Clin Pathol 2001;115:448-459.
56 Harrison P, Robinson M, Liesner R, Khair K, Cohen H, Mackie I, Machin S: The PFA-100: a potential rapid screening tool for the assessment of platelet dysfunction. Clin Lab Haematol 2002;24: 225-232.

57 Madan M, Berkowitz SD, Christie DJ, Smit AC, Sigmon KN, Tcheng JE: Determination of platelet aggregation inhibition during percutaneous coronary intervention with the platelet function analyzer PFA-100. Am Heart J 2002;144:151-158.

58 Ahn YS, Jy W, Kolodny L, Horstman LL, Mao WW, Valant PA, Duncan RC: Activated platelet aggregates in thrombotic thromboctyopenic purpura: decrease with plasma infusions and normalization in remission. Br J Haematol 1996;95:408-415.

59 Michelson AD, Barnard MR, Krueger LA, Frelinger AL III, Furman MI: Evaluation of platelet function by flow cytometry. Methods 2000 21:259-270.

60 Schmidt V, Hilberg T: ThromboFix platelet stabilizer: advances in clinical platelet analyses by flow cytometry? Platelets 2006;17:266-273.

61 Shattil SJ, Hoxie JA, Cunningham M, Brass LF: Changes in the platelet membrane glycoprotein IIb.IIIa complex during platelet activation. J Biol Chem 1985;260:11107-11114.

62 Heilmann E, Hynes LA, Burstein SA, George JN, Dale GL: Fluorescein derivatization of fibrinogen for flow cytometric analysis of fibrinogen binding to platelets. Cytometry 1994;17:287-293.

63 Lindahl TL, Festin R, Larsson A: Studies of fibrinogen binding to platelets by flow cytometry: an improved method for studies of platelet activation. Thromb Haemost 1992;68:221-225.

64 Joseph JE, Harrison P, Mackie IJ, Machin SJ: Platelet activation markers and the primary antiphospholipid syndrome (PAPS). Lupus 1998;7 (suppl 2):S48-S51.

65 Lundahl TH, Lindahl TL, Fagerberg IH, Egberg N Bunescu A, Larsson A: Activated platelets and impaired platelet function in intensive care patients analyzed by flow cytometry. Blood Coagul Fibrinolysis 1996;7:218-220.

66 Ghosh K, Khare A, Shetty S, Nair S, Kulkarni B, Mohanty D: Flowcytometric evidence of platelet activation in patients on aspirin following myocardial infarction. Natl Med J India 2006;19:73-74.

67 Meiklejohn DJ, Vickers MA, Morrison ER, Dijkhuisen R, Moore I, Urbaniak SJ, Greaves M: In vivo platelet activation in atherothrombotic stroke is not determined by polymorphisms of human platelet glycoprotein IIIa or Ib. $\mathrm{Br} \mathrm{J}$ Haematol 2001;112:621-631.

68 Roshan TM, Normah J, Rehman A, Naing L: Effect of menopause on platelet activation markers determined by flow cytometry. Am J Hematol 2005;80:257-261.

69 Zeiger F, Stephan S, Hoheisel G, Pfeiffer D, Ruehlmann C, Koksch M: P-Selectin expression, platelet aggregates, and platelet-derived microparticle formation are increased in peripheral arteria disease. Blood Coagul Fibrinolysis 2000;11:723-728.

70 Yip HK, Liou CW, Chang HW, Lan MY, Liu JS Chen MC: Link between platelet activity and outcomes after an ischemic stroke. Cerebrovasc Dis 2005;20:120-128.

71 Michelson AD, Barnard MR, Hechtman HB, MacGregor H, Connolly RJ, Loscalzo J, Valeri CR: In vivo tracking of platelets: circulating degranulated platelets rapidly lose surface P-selectin but continue to circulate and function. Proc Natl Acad Sci U S A 1996;93:11877-11882. 
72 Ferroni P, Pulcinelli FM, Lenti L, Gazzaniga PP: Is soluble P-selectin determination a more reliable marker of in vivo platelet activation than CD62P flow cytometric analysis. Thromb Haemost 1999;81: 472-473.

-73 Fijnheer R, Frijns CJ, Korteweg J, Rommes H, Peters JH, Sixma JJ, Nieuwenhuis HK: The origin of P-selectin as a circulating plasma protein. Thromb Haemost 1997;77:1081-1085.

74 McEver RP: Adhesive interactions of leukocytes, platelets, and the vessel wall during hemostasis and inflammation. Thromb Haemost 2001;86:746-756.

75 Metzelaar MJ, Korteweg J, Sixma JJ, Nieuwenhuis HK: Comparison of platelet membrane markers for the detection of platelet activation in vitro and during platelet storage and cardiopulmonary bypass surgery. J Lab Clin Med 1993;121:579-587.

76 Damas C, Vink T, Nieuwenhuis HK, Sixma JJ: The 33-kDa platelet alpha-granule membrane protein (GMP-33) is an N-terminal proteolytic fragment of thrombospondin. Thromb Haemost 2001;86:887-893.

77 Gerdsen F, Weber M, Langer F, Eifrig B, LindhoffLast E: Platelet activation markers in patients with venous thromboembolism without predisposing factors. Pathophysiol Haemost Thromb 2005;34:1-5.

-78 Fateh-Moghadam S, Li Z, Ersel S, Reuter T, Htun P, Plockinger U, Bocksch W, Dietz R, Gawaz M: Platelet degranulation is associated with progression of intima-media thickness of the common carotid artery in patients with diabetes mellitus type 2. Arterioscler Thromb Vasc Biol 2005;25: 1299-1303.

79 Danese S, Scaldaferri F, Papa A, Pola R, Gasbarrin A, Sgambato A, Cittadini A: CD40L-positive platelets induce CD40L expression de novo in endothelial cells: adding a loop to microvascular inflammation. Arterioscler Thromb Vasc Biol 2004;24:e162.

-80 Henn V, Slupsky JR, Grafe M, Anagnostopoulos I, Forster R, Muller-Berghaus G, Kroczek RA: CD40 ligand on activated platelets triggers an inflammatory reaction of endothelial cells. Nature 1998;391: 591-594.

81 Kalsch T, Nguyen XD, Elmas E, Grebert N, Suselbeck T, Kluter H, Borggrefe M, Dempfle CE: Coagulation activation and expression of CD40 ligand on platelets upon in vitro lipopolysaccharide-challenge in patients with unstable angina. Int J Cardiol 2006;111:217-223.

82 Lee Y, Lee WH, Lee SC, Ahn KJ, Choi YH, Park SW, Seo JD, Park JE: CD40L activation in circulating platelets in patients with acute coronary syndrome. Cardiology 1999;92:11-16.

83 Martinson J, Bae J, Klingemann HG, Tam Y: Activated platelets rapidly up-regulate CD40L expression and can effectively mature and activate autologous ex vivo differentiated DC. Cytotherapy 2004;6:487-497.

84 Rinder HM, Bonan JL, Rinder CS, Ault KA, Smith BR: Dynamics of leukocyte-platelet adhesion in whole blood. Blood 1991;78:1730-1737.

85 Redlich H, Vickers J, Lösche W, Heptinstall S, Kehrel B, Spangenberg P: Formation of plateletleukocyte conjugates in whole blood. Platelets 1997;8:419-425.

86 Scholz T, Temmler U, Krause S, Heptinstall S, Losche W: Transfer of tissue factor from platelets to monocytes: role of platelet-derived microvesicles and CD62P. Thromb Haemost 2002;88:1033-1038.

87 Russwurm S, Vickers J, Meier-Hellmann A, Spangenberg $\mathrm{P}$, Bredle $\mathrm{D}$, Reinhart $\mathrm{K}$, Losche W: Platelet and leukocyte activation correlate with the severity of septic organ dysfunction. Shock 2002;17 263-268.
88 Steiner S, Seidinger D, Huber K, Kaun C, Minar E, Kopp CW: Effect of glycoprotein IIb/IIIa antagonist abciximab on monocyte-platelet aggregates and tissue factor expression. Arterioscler Thromb Vasc Biol 2003;23:1697-1702.

89 Neumann FJ, Zohlnhofer D, Fakhoury L, Ott I, Gawaz M, Schomig A: Effect of glycoprotein IIb/IIIa receptor blockade on platelet-leukocyte interaction and surface expression of the leukocyte integrin Mac-1 in acute myocardial infarction. J Am Coll Cardiol 1999;34:1420-1426.

90 Zhao L, Bath PM, Fox S, May J, Judge H, Losche W, Heptinstall S: The effects of GPIIb-IIIa antagonists and a combination of three other antiplatelet agents on platelet-leukocyte interactions. Curr Med Res Opin 2003;19:178-186.

91 Zhao L, Bath P, Lösche W, Heptinstall S: Plateletmonocyte interaction and GPIIb/IIIa blockade. Thromb Haemost 2004;92:888-890.

-92 Rinder HM, Bonan JL, Rinder CS, Ault KA, Smith BR: Activated and unactivated platelet adhesion to monocytes and neutrophils. Blood 1991; 78:1760-1769.

93 Lösche W, Scholz T, Temmler U, Oberle V, Claus RA: Platelet-derived microvesicles transfer tissue factor to monocytes but not to neutrophils. Platelets 2004;15:109-116.

94 Michelson AD, Barnard MR, Krueger LA, Valeri CR, Furman MI: Circulating monocyte-platelet aggregates are a more sensitive marker of in vivo platelet activation than platelet surface P-selectin: studies in baboons, human coronary intervention, and human acute myocardial infarction. Circulation 2001;104:1533-1537.

95 Furman MI, Barnard MR, Krueger LA, Fox ML, Shilale EA, Lessard DM, Marchese P, Frelinger AL III, Goldberg RJ, Michelson AD: Circulating monocyte-platelet aggregates are an early marker of acute myocardial infarction. J Am Coll Cardiol 2001;38:1002-1006.

96 Hagberg IA, Lyberg T: Evaluation of circulating platelet-leukocyte conjugates: a sensitive flow cytometric assay well suited for clinical studies. Platelets 2000;11:151-160.

-97 Kaplar M, Kappelmayer J, Kiss A, Szabo K, Udvardy M: Increased leukocyte-platelet adhesion in chronic myeloproliferative disorders with high platelet counts. Platelets 2000;11:183-184.

98 McGregor L, Martin J, McGregor JL: Plateletleukocyte aggregates and derived microparticles in inflammation, vascular remodelling and thrombosis. Front Biosci 2006;11:830-837.

99 Camera M, Frigerio M, Toschi V, Brambilla M, Rossi F, Cottell DC, Maderna P, Parolari A, Bonzi R, De Vincenti O, Tremoli E: Platelet activation induces cell-surface immunoreactive tissue factor expression, which is modulated differently by antiplatelet drugs. Arterioscler Thromb Vasc Biol 2003;23:1690-1696.

100 Muller I, Klocke A, Alex M, Kotzsch M, Luther T, Morgenstern E, Zieseniss S, Zahler S, Preissner $\mathrm{K}$, Engelmann B: Intravascular tissue factor initiates coagulation via circulating microvesicles and platelets. FASEB J 2003;17:476-478.

101 Reutelingsperger CP, van Heerde WL: Annexin $\mathrm{V}$, the regulator of phosphatidylserine-catalyzed inflammation and coagulation during apoptosis. Cell Mol Life Sci 1997;53:527-532.

102 Reutelingsperger CP, Hornstra G, Hemker HC: Isolation and partial purification of a novel anticoagulant from arteries of human umbilical cord. Eur J Biochem 1985;151:625-629.
103 Dachary-Prigent J, Freyssinet JM, Pasquet JM, Carron JC, Nurden AT: Annexin V as a probe of aminophospholipid exposure and platelet membrane vesiculation: a flow cytometry study showing a role for free sulfhydryl groups. Blood 1993 81:2554-2565.

104 Tomer A: Platelet activation as a marker for in vivo prothrombotic activity: detection by flow cytometry. J Biol Regul Homeost Agents 2004;18: 172-177.

105 Behan MW, Fox SC, Heptinstall S, Storey RF: Inhibitory effects of $\mathrm{P} 2 \mathrm{Y} 12$ receptor antagonists on TRAP-induced platelet aggregation, procoagulant activity, microparticle formation and intracellular calcium responses in patients with acute coronary syndromes. Platelets 2005;16:73-80.

106 Chang CP, Zhao J, Wiedmer T, Sims PJ: Contribution of platelet microparticle formation and granule secretion to the transmembrane migration of phosphatidylserine. J Biol Chem 1993;268:71717178

107 Freyssinet JM: Cellular microparticles: what are they bad or good for? J Thromb Haemost 2003; $1655-1662$.

108 Flaumenhaft R: Formation and fate of platelet microparticles. Blood Cells Mol Dis 2006;36:182187

109 Vidal C, Spaulding C, Picard F, Schaison F, Melle J, Weber S, Fontenay-Roupie M: Flow cytometry detection of platelet procoagulation activity and microparticles in patients with unstable angina treated by percutaneous coronary angioplasty and stent implantation. Thromb Haemost 2001;86:784790.

110 Berckmans RJ, Neiuwland R, Boing AN, Romijn FP, Hack CE, Sturk A: Cell-derived microparticles circulate in healthy humans and support low grade thrombin generation. Thromb Haemost 2001;85:639-646.

111 Nieuwland R, Berckmans RJ, McGregor S, Boing AN, Romijn FP, Westendorp RG, Hack CE, Sturk A: Cellular origin and procoagulant properties of microparticles in meningococcal sepsis. Blood 1999;95:930-935.

112 van der Zee PM, Biro E, Ko Y, de Winter RJ, Hack CE, Sturk A, Nieuwland R: P-selectin- and CD63-exposing platelet microparticles reflect platelet activation in peripheral arterial disease and myocardial infarction. Clin Chem 2006;52:657-664.

113 Combes V, Dignat-George F, Mutin M, Sampol J: A new flow cytometry method of platelet-derived microvesicle quantitation in plasma. Thromb Haemost 1997;77:220.

114 Tocchetti EV, Flower RL, Lloyd JV: Assessment of in vitro-generated platelet microparticles using a modified flow cytometric strategy. Thromb Res 2001;103:47-55.

115 Matzdorff AC, Berchner D, Kühnel G, KemkesMatthes B, Pralle H, Voss R: Relative and absolute changes of activated platelets, microparticles and platelet aggregates after activation in vitro. Haemostasis 1999;28:277-288.

116 Behan MW, Fox SC, Heptinstall S, Storey RF: Inhibitory effects of $\mathrm{P} 2 \mathrm{Y} 12$ receptor antagonists on TRAP-induced platelet aggregation, procoagulant activity, microparticle formation and intracellular calcium responses in patients with acute coronary syndromes. Platelets 2005;16:73-80.

117 Nieuwland R, Berckmans RJ, Rotteveel-Eijkman RC, Maquelin KN, Roozendaal KJ, Jansen PG, ten Have K, Eijsman L, Hack CE, Sturk A: Cellderived microparticles generated in patients during cardiopulmonary bypass are highly procoagulant. Circulation 1997;96:3534-3541. 
118 Kim HK, Song KS, Lee ES, Lee YJ, Park YS, Lee KR, Lee SN: Optimized flow cytometric assay for the measurement of platelet microparticles in plasma: pre-analytic and analytic considerations. Blood Coagul Fibrinolysis 2002;13:393-397.

119 Shigeta O, Kojima H, Jikuya T, Terada Y, Atsumi N, Sakakibara Y, Nagasawa T, Mitsui T: Aprotinin inhibits plasmin-induced platelet activation during cardiopulmonary bypass. Circulation 1997;96: 569-574.

120 Galli M, Grassi A, Barbui T: Platelet-derived microvesicles in thrombotic thrombocytopenic purpura and hemolytic uremic syndrome. Thromb Haemost 1996;75:427-431.

-121 Morel O, Jesel L, Hugel B, Douchet MP, Zupan M, Chauvin M, Freyssinet JM, Toti F: Protective effects of vitamin $\mathrm{C}$ on endothelium damage and platelet activation during myocardial infarction in patients with sustained generation of circulating microparticles. J Thromb Haemost 2003;1:171-177.

122 Tan KT, Tayebjee MH, Macfadyen RJ, Lip GY, Blann AD: Elevated platelet microparticles in stable coronary artery disease are unrelated to disease severity or to indices of inflammation. Platelets 2005;16:368-371.

123 Craft JA, Masci PP, Roberts MS, Brighton TA, Garrahy P, Cox S, Marsh NA: Increased plateletderived microparticles in the coronary circulation of percutaneous transluminal coronary angioplasty patients. Blood Coagul Fibrinolysis 2004;15:475482.

124 Tan KT, Tayebjee MH, Lynd C, Blann AD, Lip GY: Platelet microparticles and soluble P selectin in peripheral artery disease: relationship to extent of disease and platelet activation markers. Ann Med 2005;37:61-66.

125 Eriksson M, Nelson D, Nordgren A, Larsson A: Increased platelet microvesicle formation is associated with mortality in a porcine model of endotoxemia. Acta Anaesthesiol Scand 1998;42:551-557.

126 Ogura H, Kawasaki T, Tanaka H, Koh T, Tanaka R, Ozeki Y, Hosotsubo H, Kuwagata Y, Shimazu T, Sugimoto H: Activated platelets enhance microparticle formation and platelet- leukocyte interaction in severe trauma and sepsis. J Trauma 2001;50:801-809.

-127 Schuerholz T, Sumpelmann R, Piepenbrock S, Leuwer M, Marx G: Ringer's solution but not hydroxyethyl starch or modified fluid gelatin enhances platelet microvesicle formation in a porcine model of septic shock. Br J Anaesth 2004; 92:716-721.

128 Soriano AO, Jy W, Chirinos JA, Valdivia MA, Velasquez HS, Jimenez JJ, Horstman LL, Kett DH, Schein RM, Ahn YS: Levels of endothelial and platelet microparticles and their interactions with leukocytes negatively correlate with organ dysfunction and predict mortality in severe sepsis. Crit Care Med 2005;33:2540-2546.

-129 Ahn YS, Horstman LL: Idiopathic thrombocytopenic purpura: pathophysiology and management. Int J Hematol 2002;76(suppl 2):123-31.

$>_{130}$ Nomura S, Ishii K, Kanazawa S, Inami N, Uoshima N, Ishida H, Yoshihara T, Kitayama H, Hayashi K: Significance of elevation in cellderived microparticles after allogeneic stem cell transplantation: transient elevation of plateletderived microparticles in TMA/TTP. Bone Marrow Transplant 2005;36:921-922.

131 Vanwijk MJ, Nieuwland R, Boer K, van der Post JA, Vanbavel E, Sturk A: Microparticle subpopulations are increased in preeclampsia: possible involvement in vascular dysfunction? Am J Obstet Gynecol 2002;187:450-456.
132 Osumi K, Ozeki Y, Saito S, Nagamura Y, Ito H, Kimura Y, Ogura H, Nomura S: Development and assessment of enzyme immunoassay for platelet-derived microparticles. Thromb Haemost 2001:85:326-330.

133 Nomura S, Uehata S, Saito S, Osumi K, Ozeki Y, Kimura Y: Enzyme immunoassay detection of platelet-derived microparticles and RANTES in acute coronary syndrome. Thromb Haemost 2003; 89:506-512.

134 Gurney D, Lip GY, Blann AD: A reliable plasma marker of platelet activation: does it exist? Am J Hematol 2002;70:139-144.

135 Blann AD, Lip GY: Hypothesis: is soluble Pselectin a new marker of platelet activation? Atherosclerosis 1997;128:135-138.

136 Clemetson KJ, Clemetson JM: Platelet GPIb-V-IX comples. Structure, function, physiology and pathology Semin Thromb Hemost 1995;21:130-136.

137 Strassel C, Moog S, Baas MJ, Cazenave JP, Lanza F: Biosynthesis of platelet glycoprotein V expressed as a single subunit or in association with GPIb-IX. Eur J Biochem 2004;271:3671-3677.

138 Azorsa DO, Moog S, Ravanat C, Schuhler S, Follea G, Cazenave JP, Lanza F: Measurement of GPV released by activated platelets using a sensitive immunocapture ELISA - its use to follow platelet storage in transfusion. Thromb Haemost 1999;81:131-138.

139 Ravanat C, Freund M, Mangin P, Azorsa DO, Schwartz C, Moog S, Schuhler S, Dambach J, Cazenave JP, Lanza F: GPV is a marker of in vivo platelet activation - study in a rat thrombosis model. Thromb Haemost 2000;83:327-333.

140 Blann AD, Lanza F, Galajda P, Gurney D, Moog S, Cazenave JP, Lip GY: Increased platelet glycoprotein $\mathrm{V}$ levels in patients with coronary and peripheral atherosclerosis - the influence of aspirin and cigarette smoking. Thromb Haemost 2001;86:777-783.

141 Morel O, Hugel B, Jesel L, Mallat Z, Lanza F, Douchet MP, Zupan M, Chauvin M, Cazenave JP, Tedgui A, Freyssinet JM, Toti F: Circulating procoagulant microparticles and soluble GPV in myocardial infarction treated by primary percutaneous transluminal coronary angioplasty. A possible role for GPIIb-IIIa antagonists. J Thromb Haemost 2004;2:1118-1126.

142 Atalar E, Haznedaroglu IC, Kilic H, Ozer N, Coskun S, Ozturk E, Aksoyek S, Ovunc K, Kirazli S, Ozmen F: Increased soluble glycoprotein V concentration during the acute onset of unstable angina pectoris in association with chronic cigarette smoking. Platelets 2005;16:329-333.

143 Bath PM, Butterworth RJ: Platelet size: measurement, physiology and vascular disease. Blood Coagul Fibrinolysis 1996;7:157-161.

144 Cameron HA, Phillips R, Ibbotson RM, Carson $\mathrm{PH}$ : Platelet size in myocardial infarction. Br Med J (Clin Res Ed) 1983;287:449-451.

145 Martin J, Trowbridge T, Slater D: Mean platelet volume in myocardial infarction. Br Med J (Clin Res Ed) 1983;287:1798.

146 van der Lelie J, Brakenhoff JA: Mean platelet volume in myocardial infarction. Br Med J (Clin Res Ed) 1983;287:1471.

147 Martin JF, Bath PM, Burr ML: Influence of platelet size on outcome after myocardial infarction. Lancet 1991;338:1409-1411.
148 von Ruecker A, Hufnagel P, Dickerhoff R, Murday $\mathrm{H}$, Bidlingmaier F: Qualitative and quantitative changes in platelets after coronary-artery bypass surgery may help identify thrombotic complications and infections. Klin Wochenschr 1989;67: 1042-1047.

149 Huczek Z, Kochman J, Filipiak KJ, Horszczaruk GJ, Grabowski M, Piatkowski R, Wilczynska J, Zielinski A, Meier B, Opolski G: Mean platelet volume on admission predicts impaired reperfusion and long-term mortality in acute myocardial infarction treated with primary percutaneous coronary intervention. J Am Coll Cardiol 2005;46: 284-290.

150 Khandekar MM, Khurana AS, Deshmukh SD, Kakrani AL, Katdare AD, Inamdar AK: Platelet volume indices in patients with coronary artery disease and acute myocardial infarction: an Indian scenario. J Clin Pathol 2006;59:146-149.

151 Kilicli-Camur N, Demirtunc R, Konuralp C, Eskiser A, Basaran Y: Could mean platelet volume be a predictive marker for acute myocardial infarction? Med Sci Monit 2005;11:CR387-CR392.

152 Greisenegger S, Endler G, Hsieh K, Tentschert S, Mannhalter C, Lalouschek W: Is elevated mean platelet volume associated with a worse outcome in patients with acute ischemic cerebrovascular events? Stroke 2004;35:1688-1691.

153 Butchart EG, Ionescu A, Payne N, Giddings J, Grunkemeier GL, Fraser AG: A new scoring system to determine thromboembolic risk after heart valve replacement. Circulation 2003; 108 (suppl 1):II68-74.

154 Coban E, Bostan F, Ozdogan M: The mean platelet volume in subjects with impaired fasting glucose. Platelets 2006;17:67-69.

155 Papanas N, Symeonidis G, Maltezos E, Mavridis G, Karavageli E, Vosnakidis T, Lakasas G: Mean platelet volume in patients with type 2 diabetes mellitus. Platelets 2004;15:475-478

156 Coban E, Ozdogan M, Yazicioglu G, Akcit F: The mean platelet volume in patients with obesity. Int J Clin Pract 2005;59:981-982.

157 Gyongyosi M, Strehblow C, Sperker W, Hevesi A, Garamvolgyi R, Petrasi Z, Pavo N, Ferdinandy P, Csonka C, Csont T, Sylven C, Declerck PJ, Pavo I Jr, Wojta J, Glogar D, Huber K: Platelet activation and high tissue factor level predict acute stent thrombosis in pig coronary arteries: prothrombogenic response of drug-eluting or bare stent implantation within the first 24 hours. Thromb Haemost 2006;96:202-209.

158 Schultheiss HP, Tschoepe D, Esser J, Schwippert B, Roesen P, Nieuwenhuis HK, Schmidt-Soltau C, Strauer B: Large platelets continue to circulate in an activated state after myocardial infarction. Eur J Clin Invest 1994:24:243-247.

159 Gladwin AM, Martin JF: The control of megakaryocyte ploidy and platelet production: biology and pathology. Int J Cell Cloning 1990;8:291-298.

160 van der Loo B, Martin JF: A role for changes in platelet production in the cause of acute coronary syndromes. Arterioscler Thromb Vasc Biol 1999; 19:672-679.

161 Mathur A, Robinson MS, Cotton J, Martin JF, Erusalimsky JD: Platelet reactivity in acute coronary syndromes: evidence for differences in platelet behaviour between unstable angina and myocardial infarction. Thromb Haemost 2001;85: 989-994.

162 Pizzulli L, Yang A, Martin JF, Luderitz B: Changes in platelet size and count in unstable angina compared to stable angina or non-cardiac chest pain. Eur Heart J 1998;19:80-84. 